\title{
Profil Lipida Plasma Tikus Wistar Hiperkolesterolemia pada Pemberian Gedi Merah (Abelmoschus manihot L.)
}

\author{
Nanang Gania*, Lidya I. Momuat a, Mariska M. Pitoia \\ aJurusan Kimia, FMIPA, Unsrat, Manado
}

KATA KUNCI

(Abelmoschusmanihot L.)

Kolesterol

Tikus Wistar

\begin{tabular}{l}
$\overline{\text { K E Y W O R D S }}$ \\
\hline Red Gedi (Abelmoschus \\
manihot L.) \\
Cholesterol \\
Wistar rats
\end{tabular}

*Corresponding author: Jurusan Kimia FMIPA UNSRAT, Jl. Kampus Unsrat, Manado, Indonesia 95115; Email address: nanang_gani88@yahoo.co.id Published by FMIPA UNSRAT (2013)

\section{A B S TR A K}

Tujuan penelitian ini adalah untuk mempelajari pengaruh daun gedi merah (Abelmoschus manihot L.) terhadap kadar lipida dari plasma darah hewan uji yang menderita hiperkolesterolemia. Penelitian ini menggunakan 16 ekor tikus jantan, strain Wistar berumur 2-3 bulan pertama, tikus diadaptasikan terlebih dahulu selama 8 hari dengan pemberian pakan standar, dan diakhiri masa adaptasi, sebanyak 3 ekor tikus dibedah untuk dianalisis kadar lipida plasmanya (Baseline). Tahap ke-2, tikus diberi pakan aterogenik selama 14 hari untuk meningkatkan kadar kolesterol plasmanya, dan diakhiri tahap ini sebanyak 3 ekor tikus dibedah untuk dianalisis kadar lipida plasmanya (kelompok Aterogenik). Tahap ke-3, tikus dibagi menjadi dua perlakuan, yakni: tikus yang diberi pakan standar (kelompok PS), dan tikus yang diberi pakan standar mengandung $36 \%$ pasta daun gedi merah (kelompok PG). Setiap perlakuan terdiri dari 5 ekor tikus dan diakhiri tahap perlakuan ini, semua tikus dibedah untuk dianalisis kadar lipida plasmaya menggunakan metode enzimatik kolorimetri. Pemberian pakan sebanyak $20 \mathrm{~g}$ per ekor per hari dan air minum dilakukan secara ad libitum. Hasil penelitian menunjukkan bahwa kelompok PG secara signifikan memiliki kadartotal plasma cholesterol (TPC) yang lebih rendah daripada baseline, kelompok aterogenik dan PS, kelompok PG juga memiliki kadar kolesterol dalam partikel low density lipoproteins (k-LDL) lebih rendah daripada kelompok aterogenik, dan kelompok PG memiliki kadar trigliserida (TG) yang lebih rendah daripada kelompok aterogenik dan PS. Penelitian ini menyimpulkan bahwa mengkonsumsi pakan standar mengandung 36\% pasta daun gedi merah dapat menurunkan kadar TPC, k-LDL dan trigliserida berpengaruh nyata terhadap penurunan kolesterol tikus percobaan yang hiperkolesterolemia.

\section{A B S T R A C T}

The purpose of this research was to study the effect of red gedi (Abelmoschus Manihot L.) leaves on the blood plasma lipid levels of the tested animals suffering from hypercholesterolemia. This study used 16 Wistar strain male rats, 2-3 months old with the body weight of 120 to 250 g. The tested animals were divided into three groups based on the treatments stages. At the first stage, all rats were adapted for 8 days with the standard food and at the end of the treatment 3 rats were dissected for plasma lipid level analysis (the baseline group). At the second stage, all rats were received atherogenic feeding for 14 days to increase the plasma cholesterol levels and at the end of the treatment 3 rats were dissected for plasma lipid level analysis (the atherogenic group). At the third stage, the rats were divided into two groups of treatments: the PS group and the PG group Each group consisted of 5 rats. The rats in The PS group were dengan berat $120-250 \mathrm{~g}$, dan dibagi dalam 3 tahap perlakuan. Tahap 
fed with standard food and the PG group were fed with the standard food containing $36 \%$ of red gedi leaf paste. At the end of the treatment, the rats were dissected for plasma lipid level analysis using enzymatic colorimetric methods. During the treatments, each rat was received $20 \mathrm{~g}$ of food and drinking water ad libitum. The results showedthat the total plasma cholesterol (TPC), low density lipoprotein cholesterol (LDL-C), and triglyceride levels of the rats receiving red gedi (the PGgroup) were lower compare to the other groups (thebaseline, theatherogenicandPS groups). This studyconcludedthat consumingthe standardfoodcontaining $36 \%$ of redgedileaf paste was able to reduce the cholesterol levels of hypercholesterolemiarats.

AVAILABLE ONLINE 31 Januari 2013

\section{Pendahuluan}

Daun gedi selain sebagai sayuran favorit dan sangat populer dicampurkan dalam bubur Manado, masyarakat Sulawesu Utara juga memanfaatkannya sebagai obat tradisional. Mamahit dan Soekamto (2010) melaporkan bahwa daun gedi yang direbus tanpa garam digunakan secara tradisional oleh masyarakat setempat untuk tujuan mengobati sakit ginjal, maag dan menurunkan kolesterol dalam darah.

Novriani (2009) melaporkan bahwa daun gedi mengandung senyawa tanin terkondensasi, fenolik, dan flavonoid. Suryanto (2012) menjelaskan bahwa ketiga senyawa tersebut termasuk dalam senyawa polifenol yang dapat menurunkan kadar kolesterol darah. Kadar kolesterol plasma darah, terutama kolesterol dalam partikel lipoprotein berdensitas rendah (LDL, low density lipoproteins), selalu digunakan sebagai indikator untuk mendiagnosis kemungkinan adanya gangguan jantung akibat aterosklerosis. Namun demikian kadar kolesterol plasma total (TPC, total cholesterol plasma) yang tinggi belum tentu aterogenik, bila sebagian besar kolesterolnya terdistribusi dalam partikel lipoprotein berdensitas tinggi (HDL, high density lipoproteins), sehingga penting untuk mengetahui distribusi kolesterol dalam lipoprotein plasma (Momuatet al., 2001).

Sejauh ini belum diperoleh informasi ilmiah mengenai pengaruh mengkonsumsi daun gedi, khususnya daun gedi merah (Abelmoschus manihot L.) terhadap penurunan kolesterol darah. Untuk itu, perlu dilakukan penelitian guna menguji pengaruh daun gedi merah terhadap profil lipida plasma pada penderita hiperkolesterolemia. Informasi tersebut diperoleh pada penelitian ini dengan menggunakan tikus jantan strain Wistar sebagai hewan uji. Penelitian ini bertujuan untuk mempelajari pengaruh daun gedi merah terhadap kadar lipida dari plasma darah hewan uji yang menderita hiperkolesterolemia.

\section{Metode}

Penelitian ini menggunakan 16 ekor tikus jantan, strain Wistar berumur 2-3 bulan dengan berat 120250 g yang diperoleh dari Kelurahan Kalasey Kecamatan Malalayang. Setiap tikus ditempatkan dalam satu kandang. Penerangan berasal dari cahaya matahari selama 12 jam. Pakan diberi sebanyak $20 \mathrm{~g}$ per ekor per hari, dan air diberi secara ad libitium.Sisa pakan ditimbang setiap hari, sebelum diganti dengan pakan yang baru.Berat badan tikus ditimbang setiap dua hari sekali, sekaligus untuk membersihkan kandangnya.

Sebelum diberi perlakuan, tikus (16 ekor) diadaptasikan dahulu dengan keadaan laboratorium selama 8 hari dengan pemberian pakan standar. Pada hari ke-9, dilakukan analisis kadar lipida darah terhadap 3 ekor tikus yang diambil secara acak (Tahap I).

Pada hari ke-9, semua tikus yang tersisa (13 ekor) diberi pakan aterogenik selama 2 minggu (14 hari). Pakan aterogenik diberikan untuk meningkatkan kadar kolesteroltikus.Pada hari ke-24, dilakukan analisis kadar lipida darah terhadap 3 ekor tikus yang diambil secara acak (Tahap II).

Pada hari ke-24, tikus yang tersisa (10 ekor) dibagi secara acak menjadi 2 kelompok perlakuan.Setiap kelompok terdiri atas 5 ekor tikus.Kelompok pertama diberi pakan standar (PS) dan kelompok kedua diberi pakan standar mengandung $36 \%$ pasta daun gedi merah (PG) selama 8 hari. Pada hari ke-33, dilakukan analisis kadar lipida darah terhadap semua tikus pada ke-2 kelompok perlakuan (Tahap III).

Pengambilan darah untuk analisis kadar lipida dilakukandengan cara, tikus dibius dengan menggunakan dietil eter. Dietil eter dimasukkan dalam cawan petri dan ditempatkan di bawah penyangga desikator plastik,dan ditutup rapat.Tikus dimasukkan ke dalam desikator dan ditutup rapat hingga pingsan, lalu tikus dibedah. Darah diambil melalui jantung dengan menggunakan disposable syringe berukuran $3 \mathrm{~mL}$ sebanyak $2 \mathrm{~mL}$. Darah dalam syringe disimpan dalam wadah es sampai siap dianalisis kadar lipida darah yang meliputi kadar TPC, kolesterol LDL, kolesterol HDL, dan trigliserida (TG). Prosedur analisis kadar lipida darah menggunakan metode enzimatik kolorimetri.

\subsection{Pembuatan Pakan Standar}

Komposisi pakan standartertera pada Tabel 1. Semua bahan yang sudah disiapkan, dimasukkan dalam wadah dan dicampurkan menggunakan 
blender hingga rata kemudian dipanaskan \pm 10 menit pada suhu $\pm 120^{\circ} \mathrm{C}$.

\subsection{Pembuatan Pakan Aterogenik}

Pakan aterogenik dibuat dengan mencampurkan 100 g lemak kambing (10\%) dan 50 g kuning telur (5\%) dalam 1000 g pakan standar. Sebelum dicampur dengan pakan standar, lemak kambing dipanaskan dahulu hingga mancair, dan kuning telur diambil dari telur yang telah direbus.

\subsection{Pembuatan Pakan Mengandung Gedi Merah}

Daun gedi merah segar yang baru dipetik dicuci dengan air bersih, ditiriskan dan dikeringanginkan selama 2 hari di tempat yang teduh. Sebanyak $79 \mathrm{~g}$ daun gedi merah direbus dalam air $900 \mathrm{~mL}$ (hingga daun terendam air) selama \pm 30 menit pada suhu 100 ${ }^{\circ} \mathrm{C}$ kemudian didinginkan dan diblender hingga halus bersama air rebusan, dan menghasilkan pasta gedi sebanyak $364.6 \mathrm{~g}$.
Banyaknya daun gedi yang digunakan dalam $P G$ (pakan Gedi) untuk tikus ditentukanberdasarkan konsumsi harian buah dan sayur menurut WHO sebesar 400 g (Kurniawan, 2007). Dosis ini dikonversi ke dosis untuk tikus yang ditentukan padaberat badan manusia $70 . \mathrm{Kg}$ dan tikus 200.g (Laurence and Bacharach dalam Santosa dan Hertiani, 2005). Berdasarkan perhitungan konversi dosis diperoleh nilai konversi dosis untuk manusia ke tikus adalah 0.018. Sehingga konsumsi sayur untuk manusia $400 \mathrm{~g}$ per hari, untuk tikus menjadi $0.018 \mathrm{x}$ 400 g per hari atau sebesar 7.2 g per hari.Jika pakan yang diberikan untuk tikus sebanyak $20 \mathrm{~g}$ per hari, maka konsentasi gedi dalam pakan sebesar 36\%. Jadi, untuk membuat pakan gedi sebanyak $1000 \mathrm{~g}$ dibutuhkan $640 \mathrm{~g}$ pakan standar dan $360 \mathrm{~g}$ pasta gedi.

\section{Tabel 1 - Komposisi Pakan Standar}

\begin{tabular}{|l|l|l|}
\hline Bahan-Bahan Campuran & Nama Bahan & Jumlah (\%) dalam 1000 g \\
\hline Protein & Putih telur & 10 \\
Minyak & Bimoli & 8 \\
Campuran multivitamin dan mineral & Ultravita & 1 \\
Selulosa & CMC & 1 \\
Air & Air & 5 \\
Pati jagung untuk membuat $100 \%$ & Tepung jagung & \\
\hline
\end{tabular}

\subsection{Analisis Data}

Analisis data penelitian menggunakan Rancangan Acak Lengkap dengan 4 perlakuan, yaitu baseline, kelompok aterogenik, pakan standar (PS), dan pakan gedi (PG). Bila hasil analisis ragamnya berbeda nyata (signifikan), maka untuk mengetahui perlakuan mana yang berbeda digunakan uji lanjut Beda Nyata Terkecil (BNT) pada $\alpha=5 \%$. Analisis ini dilakukan dengan bantuan software SPSS versi 15.

\section{Hasil dan Pembahasan}

\subsection{Konsumsi Pakan dan Bobot Badan Tikus Percobaan}

Hasil pengamatan terhadap bobot badan dan konsumsi pakan tikus selama masa perlakuan ditunjukkan pada Tabel 2. Selama masa perlakuan, terjadi kenaikan bobot badan yang berbeda diantara kelompok tikus. Kenaikan bobot badan tikus kelompok PG lebih rendah (183.14 g) dibandingkan tikus kelompokPS (193.14 g). Kelompok PG mengkonsumsi pakan harian rata-rata lebih banyak $(11.94 \mathrm{~g})$ dibandingkan kelompok PS $(7.97 \mathrm{~g})$, baseline (10.13 g) dan kelompok aterogenik (10.14 g), namun kelompok PG memiliki bobot badan yang lebih rendah. Lebih rendahnya kenaikan bobot badan tikus pada kelompok PG daripada kelompok PSdiduga disebabkan oleh tingginya kandungan serat dalam PG. Serat dalam pakan tidak dapat diserap oleh dinding usus dan dikeluarkan oleh tubuh melalui feses.

\subsection{Kadar Kolesterol Total Plasma (TPC)}

Kadar TPC kelompok aterogenik lebih tinggi $(150.00 \pm 26.46 \mathrm{mg} / \mathrm{dL})$ daripada baseline $(93.33 \pm 5.77 \mathrm{mg} / \mathrm{dL})$, kelompok PS $(85.00 \pm 7.07$ $\mathrm{mg} / \mathrm{gL})$ dan PG $(60.00 \pm 6.12 \mathrm{mg} / \mathrm{dL})$. Hasil analisis kadar kolesterol total plasma ditunjukkan pada Gambar 1.

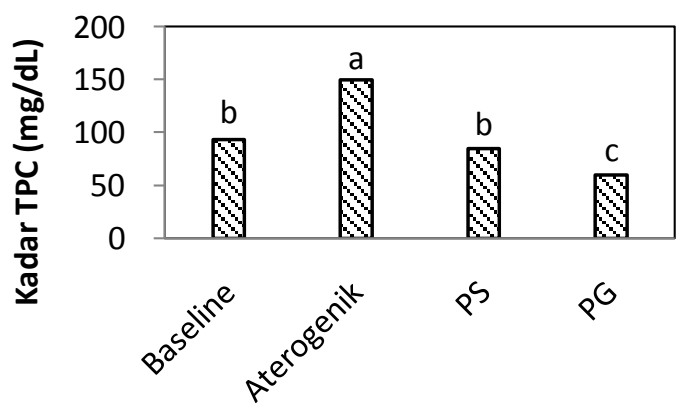

Kelompok Perlakuan

\section{Gambar 1 - Diagramkadar TPC pada tiap kelompok perlakuan.}

Lehninger (1988) menjelaskan bahwa kolesterol tubuh berasal dari dua sumber, yaitu dari makanan yang dikonsumsi (kolesterol eksogen) dan diproduksi 
sendiri oleh tubuh (kolesterol endogen).Di dalam tubuh tidak dapat dibedakan antara kolesterol eksogen dan endogen.

Hasil analisis kadar TPCdarah tikus Wistar pada setiap kelompok perlakuan disajikan dalam Gambar1. Hasil analisis tersebut menunjukan adanya perbedaan nyata kadar TPC antara kelompok aterogenik dengan baseline, kelompok PS dan PG $(p=0,000)$. Hasil uji tersebut juga menunjukan adanya perbedaan nyata antara kadar TPC kelompok PS dan PG $(p=0.007)$, namun tidak berbeda nyata antara basline dengan kelompok PS $(p=0.372)$. Hasil ini menunjukkan bahwa pemberian pakan standar mengandung 36\% pasta daun gedi merah selama 1 minggu mampu menurunkan secara nyata kadar TPC penderita hiperkolesterolemia $(p<0.005)$. Novriani (2009) melaporkan bahwa dalam gedi merah mengandung total fenolik dan flavonoid yang lebih tinggi daripada gedi hijau. Senyawa fenolik dan flavonoid digolongkan dalam senyawa polifenol. Menurut Yokozawa et. al. (2002), senyawa polifenol dapat menurunkan kadar kolesterol plasma dengan cara menghambat absorbsi kolesterol oleh usus dan meningkatkan reaksi pembentukan asam empedu dari kolesterol untuk kemudian diekskresikan melalui feses.Reaksi pembentukan asam empedu dari kolesterol dapat dilihat pada Gambar 2.

Tabel 2 - Bobot badan tikus dan bobot pakan yang dikonsumsi pada setiap kelompok perlakuan

\begin{tabular}{|l|l|l|l|l|l|}
\hline Perbandingan & Awal $(\mathrm{g})$ & Basline $(\mathrm{g})$ & Aterogenik (g) & PS (g) & PG (g) \\
\hline Bobot Badan & 188.00 & 193.90 & 187.23 & 193.14 & 183.14 \\
\hline BobotPakan & - & 10.13 & 10.14 & 7.97 & 11.94 \\
\hline
\end{tabular}

Keterangan $\mathrm{PS}=$ pakan standar; $\mathrm{PG}=$ pakan standar mengandung gedi merah

\subsection{Kadar Kolesterol High Density Lipoproteins (k- HDL)}

Hasil analisis kadar kolesterol HDL darah tikus Wistar pada setiap kelompok perlakuan disajikan dalam Gambar 3. Kadar kolesterol HDL kelompok aterogenik $(47.00 \pm 1.73 \mathrm{mg} / \mathrm{dL})$ tidak berbeda nyata $(p>0.250)$ dengan baseline $(51.33 \pm 8.02 \mathrm{mg} / \mathrm{dL})$, tetapi secara nyata lebih rendah daripada kelompok PS dan PG. Kadar kolesterol HDL kelompok PG $(35.60 \pm 2.19 \mathrm{mg} / \mathrm{dL})$ tidak berbeda nyata dengan kelompok PS $(39.60 \pm 4.39 \mathrm{mg} / \mathrm{dL})(p=0.175)$.

Kadar kolesterol HDL darah yang tinggi sangat bermanfaat dalam menurunkan risiko aterosklerosis, karena HDL berfungsi mengangkut kolesterol dari jaringan periferal menuju ke hati hingga mencegah terjadinya pengapuran (Hartoyo et al., 2008). Hasil penelitian sejenis dilaporkan oleh Bahaudin (2008) bahwa kadar kolesterol HDL yang tinggi pada tikus wistar, sangat bermanfaat dalam menurunkan risiko terjadinya aterosklerosis. Fungsi k-HDL inilah yang menyebabkan k-HDL disebut juga sebagai kolesterol baik karena memiliki efek antiaterogenik yaitu mengangkut kolesterol bebas dari pembuluh darah dan jaringan lain menuju hati, kemudian organ hati mengekskresikannya melalui empedu. Peningkatan kadar HDL sebesar 1 poin dapat menurunkan risiko penderita penyakit jantung koroner sebesar 2-3\% (Khal's dalam Hartoyo et al.,2008).Kadar kolesterol HDL plasma darah tikus yang normal yaitu $\geq 35 \mathrm{mg} / \mathrm{dL}$ (Schaerfer et al. dalam Hartoyo et al., 2008).

\subsection{Kadar Kolesterol Low Density Lipoproteins (k- LDL)}

Hasil analisis kadar kolesterol LDL darah tikus Wistar pada setiap kelompok perlakuan disajikan dalam Gambar 4. Kadar kolesterol LDL kelompok aterogenik $(69.3 \pm 33.5 \mathrm{mg} / \mathrm{dL})$ yang telah diberi pakan tinggi kolesterol dan lemak mengalami peningkatan yang berbeda nyata $(p=0,004)$ dengan baseline $(24.67 \pm 8.50 \mathrm{mg} / \mathrm{dL})$. Kadar kolesterol LDL tikus yang menderita hiperkolesterolemia menurun secara nyata pada pemberian pakan standar $(22.80 \pm 11.30 \mathrm{mg} / \mathrm{dL})$ dan pakan standar mengandung $36 \%$ pasta daun gedi merah $(6.80 \pm 1.11$ $\mathrm{mg} / \mathrm{dL}) \quad(p<0,05)$. Kadar kolesterol LDL pada kelompok PS dan PG tidak berbeda nyata $(p=0.132)$.

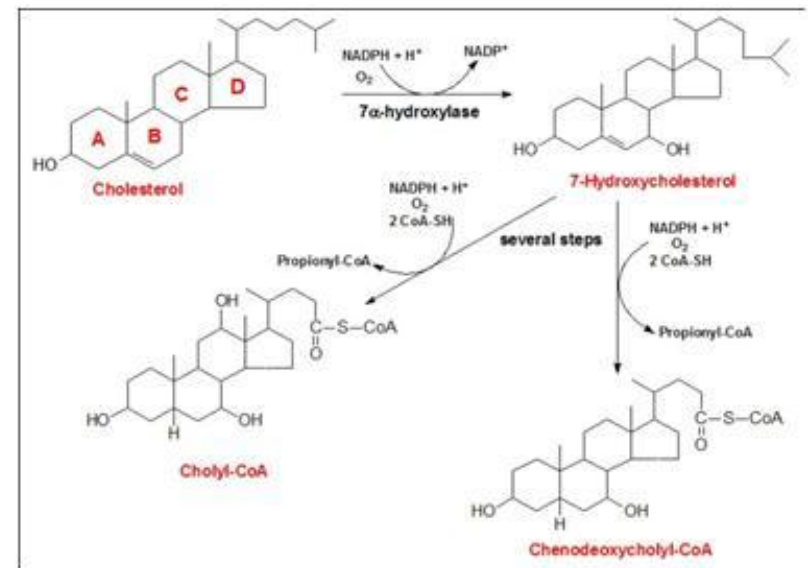

\section{Gambar 2 - Reaksi Pembentukan Asam Empedu dar Kolesterol}

Penurunan kadar kolesterol LDL dari tikus hiperkolesterolemia pada pemberian pakan standar (PS) dan pakan standar mengandung gedi merah (PG) disebabkan oleh rendahnya kandungan kolesterol dan lemak dalam kedua pakan tersebut. Mengkonsumsi makanan yang berkolesterol dan berlemak tinggi dapat meningkatkan kadar kolesterol dalam plasma darah, dan sebaliknya menghindari makanan tersebut dapat menurunkan kadar kolesterol plasma darah. Kadar k-LDL kelompok PS 
dan PG tidak berbeda nyata, namun kelompok PG cenderung memiliki kadar kolesterol LDL yang relatif lebih rendah dari PS. Hal ini diduga kerena daun gedi merah mengandung senyawa polifenol dan serat yang dapat menurunan kadar k-LDL.

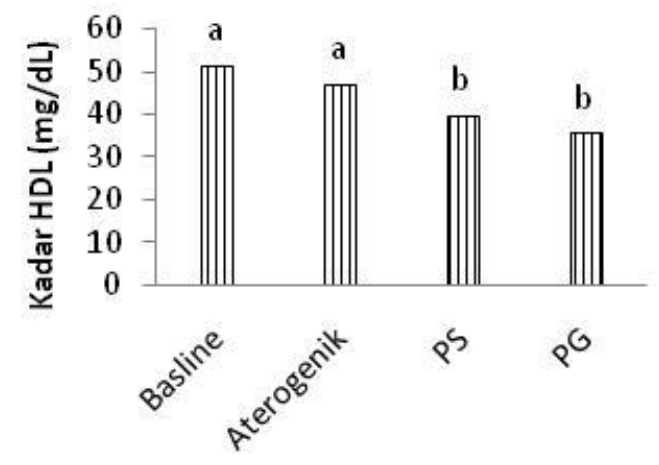

Kelompok Perlakuan

Gambar 3 - Diagram kadar kolesterol HDL pada tiap kelompok perlakuan.

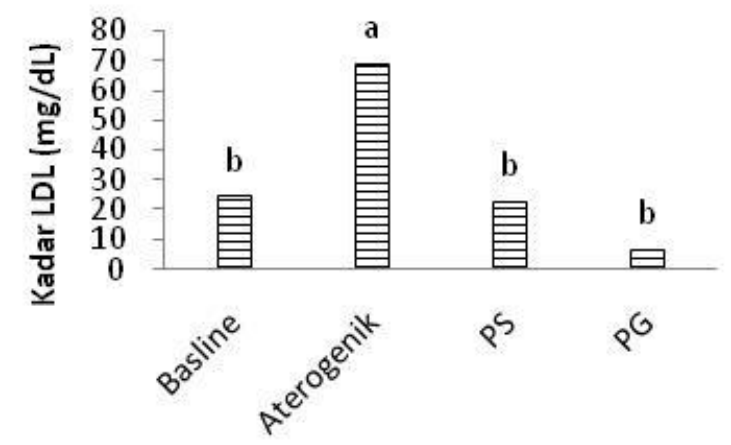

\section{Kelompok Perlakuan}

Gambar 4 - Diagram kadarLDL Cholesterol pada tiap kelompok perlakuan.

Wresdiyati et al. (2011) melaporkan bahwa serat pangan dapat mengikat kolesterol LDL secara langsung, juga mengikat asam empedu dan menghambat sirkulasi enterohepatik asam empedu. Mekanisme ini akan memacu kehilangan kolesterol LDL dengan cara meningkatkan pengeluaran kolesterol LDL melalui feses. Hal serupa dilaporkan juga oleh Hartoyo et al. (2008) yang menyatakan bahwa penambahan beberapa jenis serat pada manusia dapat menurunkan kadar k-LDL.

\subsection{Kadar Trigliserida}

Hasil analisis kadar trigliserida darah tikus Wistar disajikan dalam Gambar 5. Kadar trigliserida kelompok PG $(88.00 \pm 13.04 \mathrm{mg} / \mathrm{dL})$ secara nyata lebih rendah dari kelompok aterogenik $(128.33 \pm 24.66 \mathrm{mg} / \mathrm{dL})$ dan kelompok PS $(123.00 \pm 17.18 \mathrm{mg} / \mathrm{dL})$, tetapi tidak berbeda nyata dengan baseline $(103.33 \pm 25.17 \mathrm{mg} / \mathrm{dL})$.

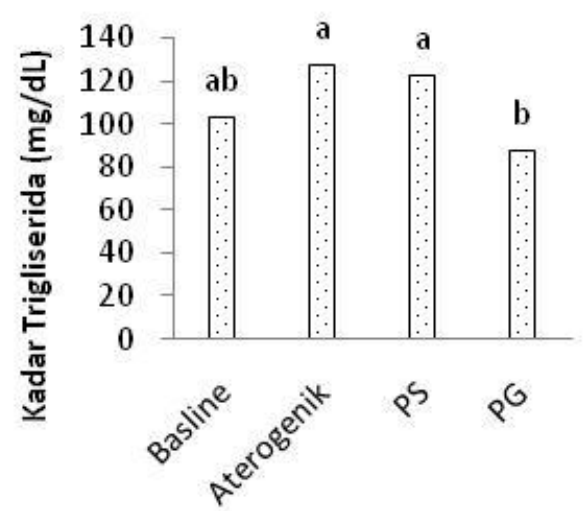

Kelompok Perlakuan

Gambar 5 - Diagram KadarTrigliserida pada Tiap Kelompok Perlakuan.

Kadar trigliserida plasma darah tikus pada kelompok PG lebih rendah daripada kelompok aterogenik dan PS. Hasil tersebut menunjukkan bahwa pemberian gedi merah dapat menurunkan kadar trigliserida plasma.

Secara umum, kadar trigliserida pada semua perlakuan dalam penelitian ini masih berada dalam kisaran normal yaitu antara 26-145 mg/dL. Kadar trigliserida dalam darah dipengaruhi oleh kadar lemak yang dicerna dalam makanan. Rimadianti dalam Sudrajat (2008) mengungkapkan bahwa naik turunnya kadar trigliserida darah dipengaruhi oleh jumlah lemak yang dikonsumsi.

\section{Kesimpulan}

Penelitian ini menyimpulkan bahwa pemberian pakan standar mengandung 36\% pasta daun gedi merah (Abelmoschus manihot L.) dapat menurunkan kadar TPC, kolesterol LDL dan trigliserida plasma darah hewan uji yang menderita hiperkolesterolemia.

\section{Daftar Pustaka}

Bahaudin, A. 2008. Profil lemak darah dan respon fisiologis tikus putih yang diberi pakan gulai daging domba dengan penambahan jeroan [Skripsi]. IPB. Bogor.

Hartoyo, A., Dahrulsyah, N. Sripalupi dan P. Nugroho. 2008. Pengaruh Fraksi Karbohidrat Kacang Komak (Lablab Purpureus (L) Sweet). Jurnal teknologi dan industri pangan, 19: 25-31.

Kurniawan, A. 2007.Kebijakan Penanggulangan Masalah Defisiensi Seng (Zn) Di Indonesia.Prosisding Seminar Nasional Penanggulangan Masalah Defisiensi seng (Zn); IPB, Bogor. HIm 69-76 
Lehninger, A.L. 1988. Dasar-Dasar Biokimia, Jilid 1. Terjemahan Maggy Thenawidjaja. Erlangga, Jakarta.

Mamahit, L. dan N.H. Soekamto. 2010. Satu Senyawa Asam Organik Yang Diisolasi Dari Daun Gedi (Abelmoschus manihot L. Medik) Asal Sulawesi Utara. Chem. Prog. 3: 42-45.

Momuat, L.I, Sulistiyani, A. Khomsan dan D. Sajuthi.2001. Minyak Sawit Mempercepat Regresi Aterosklerosis Aorta Pada Kelinci Hiperkolesterolemia Ringan, Tetapi Tidak Pada Yang Hiperkolesterolemia Berat.Media Gizi dan Keluarga, 225: 26-34.

Novriani.2009. Perbandingan Aktivitas Antioksidan Dari daun Gedi hujau dan merah [Skripsi].UKIT.Tomohon.

Santosa, C.M. dan T. Hertiani. 2005. Kandungan senyawa kimia dan efek ekstrak air Daun Bangunbangun (Coleus amboinicus, L.) pada aktivitas fagositosis netrofil tikus putih (Rattus norvegicus). Majalah Farmasi Indonesia, 16: 141-148.
Sudrajat J. 2008. Prifil Lemak, Kolesterol Darah, Dan Respon Fisiologi Tikus Wistar Yang Diberi Ransum Mengandung Gulai Daging Sapi Lean [skripsi]. IPB. Bogor.

Suryanto, E. 2012. Fitokimia Antioksida. Putra Media Nusantara. Surabaya

Tambahani, J.C. 2002.Kontribusi Tinutuan_(Bubur Manado) Terhadap Konsumsi Gizi Anak Sekolah Taman Kanak-Kanak Di Kabupaten Minahasa Provinsi Sulawesi Utara [Tesis]. ITB. Bandung.

Wrediyati, T., A.B. Hartanta dan M. Astawan.2011. Tepung Rumput Laut (Eucheuma Cottonii) Menaikkan Level Superoksida Dismutase (Sod) Ginjal Tikus Hiperkolesterolemia.Jurnal Veteriner, 12: $126-135$.

Yokozawa, T., T. Nakagawa dan K. Kitani. 2002. Antioxidative activity of green tea polyphenol in cholesterol-fed rats. Journal of Agricultural and Food Chemistry, 50:3549-35. 